Article

\title{
Novel Polyclonal Antibody Raised against Tetrodotoxin Using Its Haptenic Antigen Prepared from 4,9-anhydrotetrodotoxin Reacted with 1,2-Ethaneditiol and Further Reacted with Keyhole Limpet Hemocyanin
}

\author{
Shigeru Sato *, Suzuka Takaishi, Ko Yasumoto and Shugo Watabe \\ School of Marine Biosciences, Kitasato University, Sagamihara-shi, Kanagawa 252-0373, Japan; \\ mf16004@st.kitasato-u.ac.jp (S.T.); yasumoto@kitasato-u.ac.jp (K.Y.); swatabe@kitasato-u.ac.jp (S.W.) \\ * Correspondence: shigeru@kitasato-u.ac.jp; Tel.: +81-42-778-9394
}

Received: 30 July 2019; Accepted: 19 September 2019; Published: 20 September 2019

\begin{abstract}
A novel polyclonal antibody against tetrodotoxin (TTX) was raised using its haptenic antigen, where 4,9-anhydroTTX was reacted with 1,2-ethanedithiol and this derivative was further reacted with keyhole limpet hemocyanin (KLH). This newly designed antigen (KLH-TTX) was inoculated into rabbits, resulting in the production of the specific polyclonal antibody, which reacted well with TTX and its analogs, 4-epiTTX, 11-oxoTTX and 5,6,11-trideoxyTTX, except for 4,9-anhydroTTX. The enzyme-linked immunosorbent assay (ELISA) system using this specific antibody was also developed in the present study. This newly developed polyclonal antibody with analytical procedures using direct one-step ELISA is useful to detect TTX and its analogs in toxic organisms and also disclose the mechanisms involved in their metabolic pathways and accumulation of TTX.
\end{abstract}

Keywords: tetrodotoxin; tetrodotoxin analogs; pufferfish; polyclonal antibody; ELISA

Key Contribution: A novel polyclonal antibody against tetrodotoxin was developed. ELISA kit using this antibody has been demonstrated to detect tetrodotoxin and its various analogues effectively.

\section{Introduction}

Tetrodotoxin (TTX), one of the most potent natural neurotoxins [1,2], has been first detected in pufferfish [3,4] and later determined for its unique structure by Tsuda et al. [5], Woodward [6] and Goto et al. [7]. Subsequently, TTX was found in various organisms, including vertebrates and invertebrates [8-11] and even bacteria [12-14]. These findings suggest that TTX is first produced in microbes and then accumulated in invertebrate and vertebrates through food webs $[15,16]$. However, bacteria produce TTX very marginally and the mechanisms involved in the accumulation of TTX at large amounts in eukaryotes have remained unknown [16,17]. Recent studies revealed that various TTX analogs, such as 4-epiTTX, 11-oxoTTX and 5,6,11-trideoxyTTX, exist together with TTX in diverse animals [18], although their concentrations in toxic organisms are much lower than those of TTX except 5,6,11-trideoxyTTX [19-24]. Their metabolic pathways to be converted to TTX have remained largely unknown.

To cope with such uncertainties, it is important to develop sensitive methods to detect TTX or its analogs specifically. Such approaches to certainly determine small amounts of these compounds will help find metabolic pathways and biological significance of TTX in various organisms. One of such approaches is to obtain a specific antibody. However, a monoclonal antibody so far prepared reacts with 
only TTX, but hardly with its analogs [25-28]. Recently developed liquid chromatography connected with mass spectrometry has very high sensitivity to the above-mentioned compounds with certain specificity $[20,21]$. However, this approach has some limitations where TTX and its analogs cannot be well discriminated from contaminants when biological materials or their partially purified samples are directly analyzed. These contaminants are usually present in the extracts from TTX-containing organisms $[20,21]$. If we can raise a polyclonal antibody specific to TTX and its analogs, we can detect these compounds even at a marginal amount and even in the presence of contaminants. Such sensitive and multipotent antibody is expected to make clear the above-mentioned ambiguities, for example, localization of TTX in TTX-containing animals [29-34] and possibly even TTX analogs or metabolites without TTX. Such antibody is also desired in sanitary backgrounds to avoid any happenings to ingest toxic animals $[30,31]$.

The present study developed a novel polyclonal antibody against TTX using its haptenic antigen, where 4,9-anhydroTTX was reacted with a dithiol reagent and this derivative was further reacted with keyhole limpet hemocyanin (KLH). This procedure has been successfully adopted to raise a polyclonal antibody against paralytic shellfish toxin (PSTs) $[35,36]$. The antibody in the present study reacted with not only TTX but also its analogs, although the reactivity of the antibody varied depending on the toxin structures. The enzyme-linked immunosorbent assay (ELISA) system using this novel antibody was also developed in this study.

\section{Results}

\subsection{Reaction of 4,9-anhydroTTX and Dithiol Reagents}

Yotsu-Yamashita et al. [20] reported that L-cysteine reacts with 4,9-anhydroTTX and forms an adduct in which C4 position of TTX couples with the sulfur atom of L-cysteine. In the present study, 4,9-anhydroTTX (initial concentration: $1.0 \mathrm{mM}$ ) in the reaction mixture with 1,2-ethaneditiol (EDT; Sigma-Aldrich, St. Louis, MO, USA) decreased during incubation at $37{ }^{\circ} \mathrm{C}$ and completely disappeared after $30 \mathrm{~min}$. Similar results were observed when 4,9-anhydroTTX was incubated with $( \pm$ )-dithiothreitol (DTT). After incubation for $30 \mathrm{~min}$, the reaction mixtures with EDT or DTT showed no peak corresponding to 4,9-anhydroTTX, 4-epiTTX nor TTX in the HPLC fluorometric analysis (Table S1). These results suggest that 4,9-anhydroTTX reacted with EDT and DTT to form adducts, in which their dithiols coupled to the C4 position of TTX.

\subsection{KLH-TTX Conjugate Used for Antigen}

Figure 1 shows the estimation structure of antigen (KLH-TTX conjugate). A $21.6 \mu \mathrm{g}$ amount of antigen was obtained as a precipitate after dialysis. When a 216- $\mu$ g equivalent portion was suspended in $1 \mathrm{~mL}$ of water, a peak corresponding to $36.6 \mu \mathrm{M}$ of TTX was detected in the fluorometric analysis, where KLH itself showed no fluorescence. This result indicates at least $5.4 \%(w / w)$ of TTX was coupled with KLH.

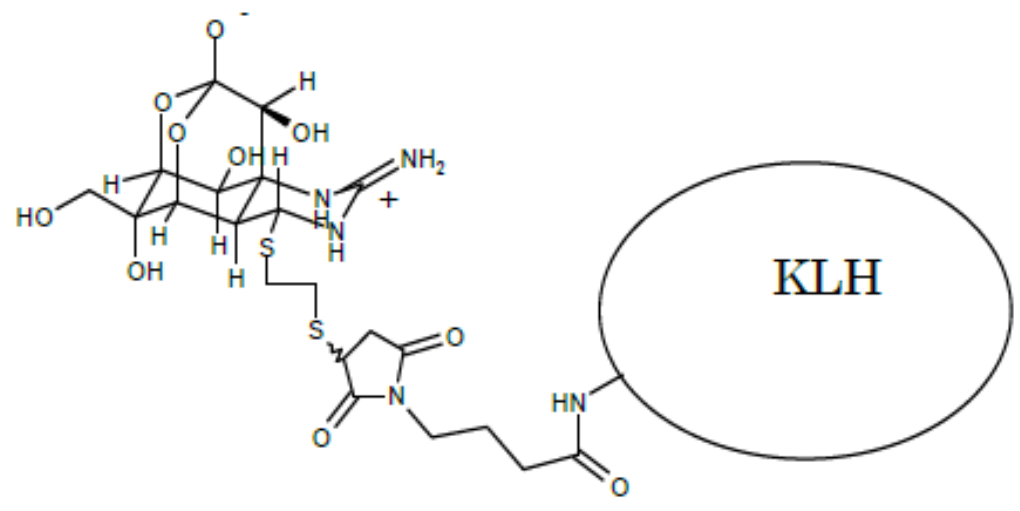

Figure 1. The estimated structure of the conjugated tetrodotoxin (TTX) antigen (KLH-GMBS-EDT-TTX). 


\subsection{Development of Antibody against TTX}

High titers appeared after immunization for one month. In Figure 2, titers are expressed as the amount of TTX (nmol) adsorbed in $1 \mathrm{~mL}$ serum. One rabbit (No.1) died during immunization, and four rabbits survived until the final stage. Titers at the first stage (pre-inoculation), corresponding to non-specific adsorption, were less than $1.0 \mathrm{nmol} / \mathrm{mL}$ serum, whereas those at the final stage (14th) varied from 4.0 to $24.5 \mathrm{nmol} / \mathrm{mL}$ serum. The antisera (No.2-No.5 rabbits, 7th) also adsorbed 4-epiTTX, 11-oxoTTX and 5,6,11-trideoxyTTX at 60 to $80 \mathrm{~mol} \%$ amount of TTX, but hardly adsorbed 4,9-anhydroTTX (less than $1.0 \mathrm{nmol} / \mathrm{mL}$ serum). The amounts of TTX and its analogs trapped in No.2 rabbit are shown in Figure 3.

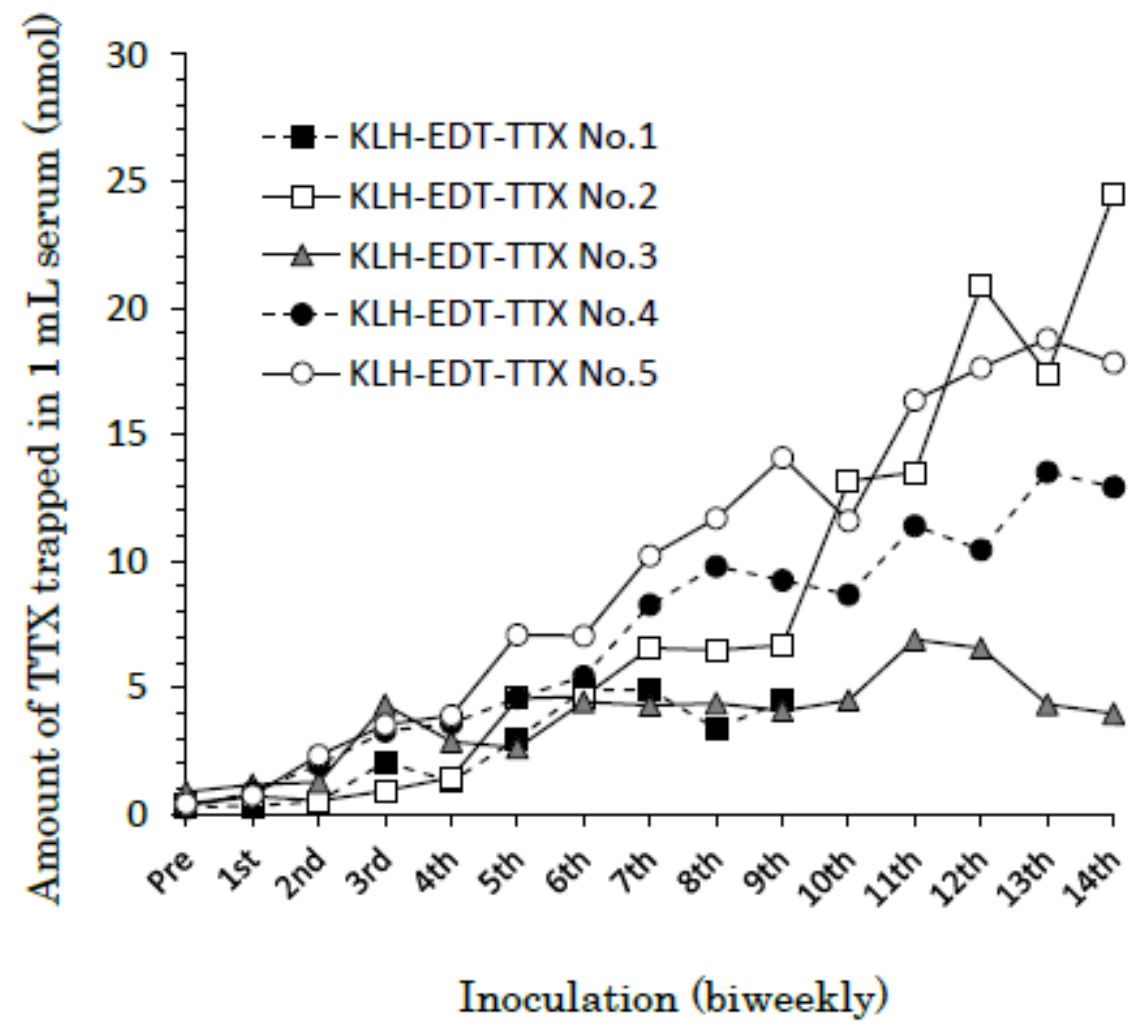

Figure 2. Changes in the titer of rabbits inoculated with KLH-TTX. Titers are expressed in the ordinate as the amount of TTX (nmol) adsorbed in $1 \mathrm{~mL}$ serum.

\section{Toxins Trapped in $1 \mathrm{~mL}$ serum (nmol)}
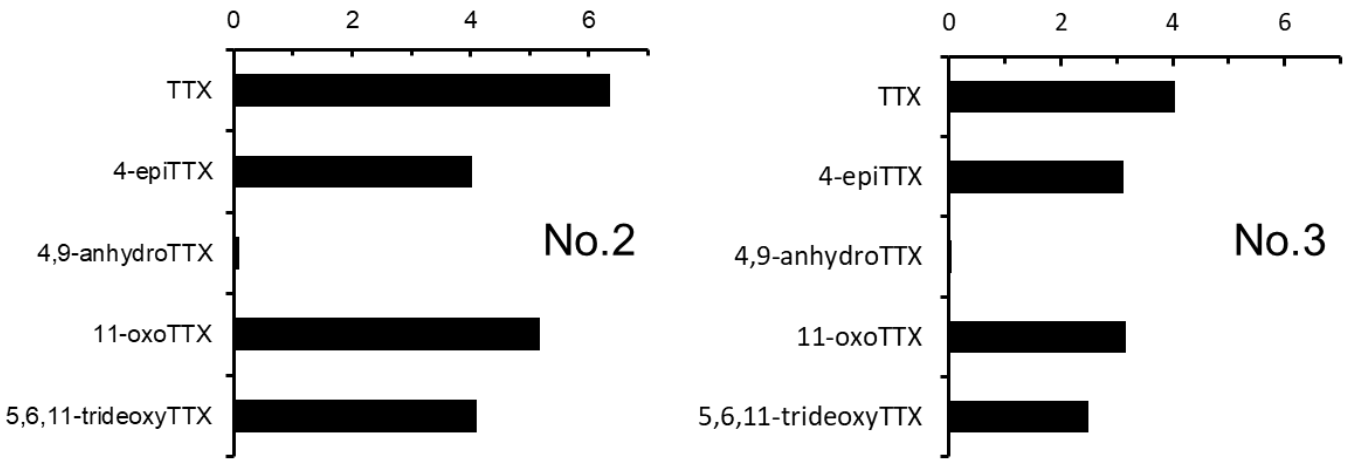

Figure 3. The amounts of TTX and its analogs trapped in a rabbit (No.2 and No.3) serum. 


\subsection{Conjugate of Biotin and TTX}

The conjugate of biotin and TTX (Biotin-TTX, Figure 4) was prepared by the reaction of DTT-TTX with maleimide-PEG2-biotin. The conjugate in the reaction mixture was purified by Bio-Gel P-2 column chromatography and $1.8 \mu \mathrm{g}$ amount of biotin-TTX $(1.73 \mu \mathrm{mol})$ was obtained as a white powder. A part of the conjugate thus obtained was used to analyze its conformation by TOFMS. The data showed significant peaks at $\mathrm{m} / \mathrm{z} 491.1707$ and $\mathrm{m} / \mathrm{z}$ 981.3337, corresponding to the pseudo-molecular ion peaks of $\mathrm{m} / \mathrm{z}[\mathrm{M}+2 \mathrm{H}]^{++}(\mathrm{m} / \mathrm{z}$ calcd. 491.1723$)$ and $[\mathrm{M}+\mathrm{H}]^{+}(\mathrm{m} / \mathrm{z}$ calcd. 981.3368$)$ of the target compound, respectively.

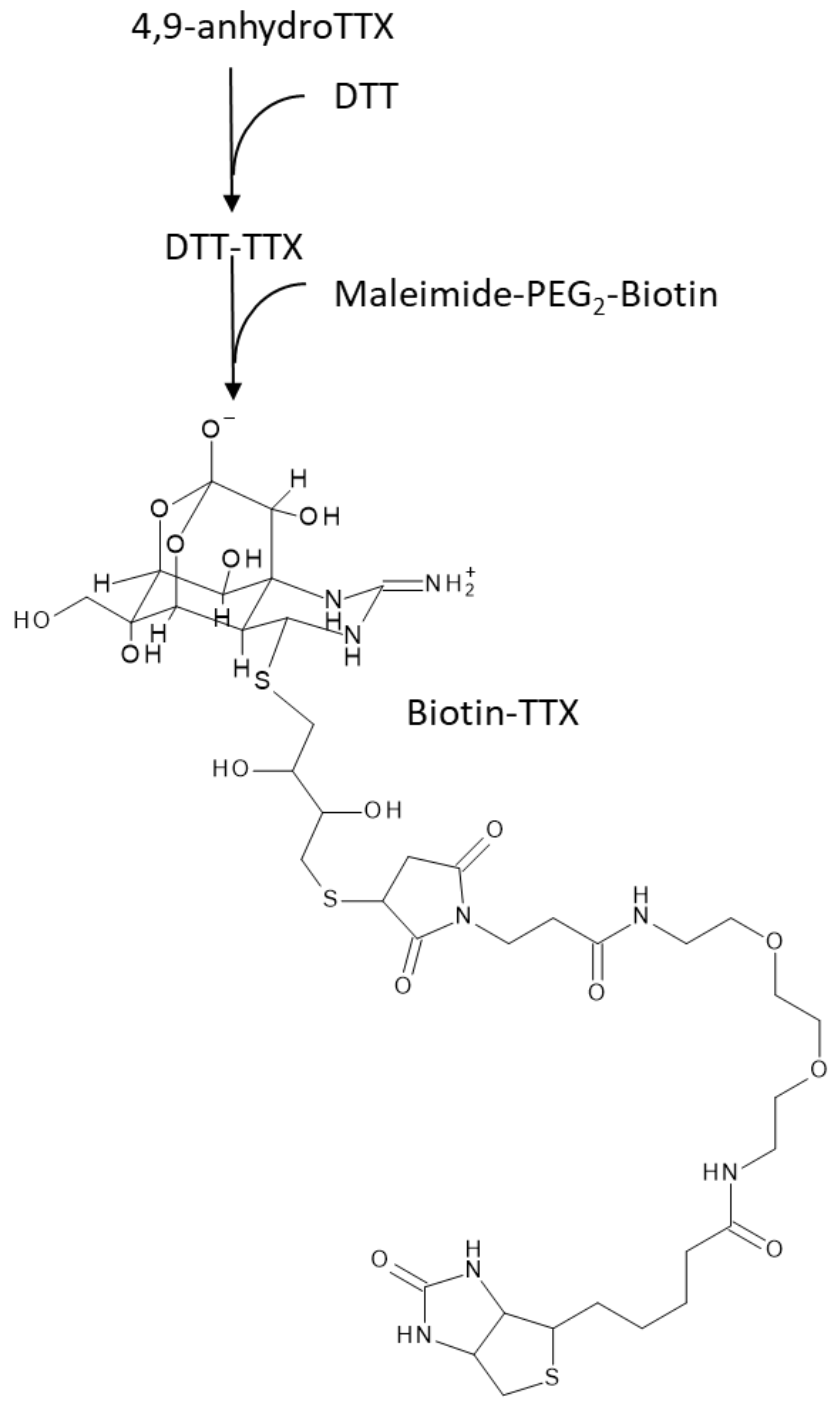

Figure 4. The estimation structure of the antigen labeled with biotin (Biotin-DTT-TTX).

\subsection{Reactivity of the Antibody to TTX and Its Analogs and PSTs in ELISA}

Direct one-step ELISA was carried out using the purified antibody obtained from rabbit No.3. Biotin-TTX described above was used as a labeled toxin. As shown in Figure 5, detection limit and working range for TTX were around $3 \mathrm{nM}$ and $10-300 \mathrm{nM}$, respectively. The association constant for TTX was $3.42 \times 10^{8} \mathrm{M}^{-1}$, whereas the range for quantification was between 10 and $100 \mathrm{nM}$. TTX analogs, such as 4-epiTTX, 11-oxoTTX, 5,6,11-trideoxyTTX, showed high reactivity to the antibody in ELISA, whereas 4,9-anhydroTTX did not. TTX and its analogs (TTXs) are known to block voltage-dependent sodium channel specifically [1,2]. The chemical structures of paralytic shellfish toxins (PSTs) are very different from those of TTXs, though PSTs have the same pharmacological activity. As shown in 
Figure 6, no cross-reaction was observed when PST components, GTX1/4, GTX2/3, C1/2, neoSTX nor dcSTX, were separately analyzed by the ELISA. Thus, the antibody obtained in the present study distinguishes between TTXs and PSTs. In addition, KLH itself did not react with the antibody (Table S2).

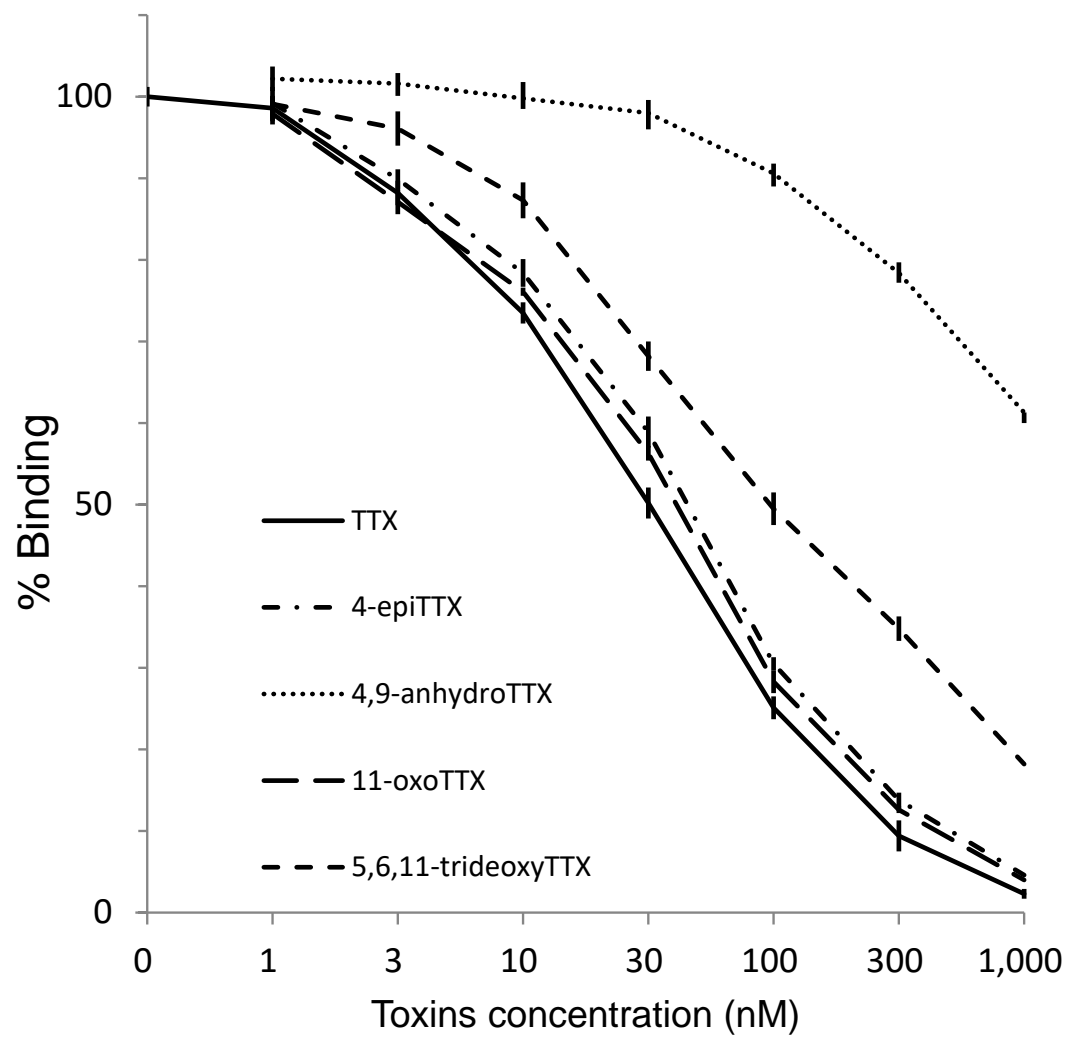

Figure 5. The reactivity of the antibody against TTX and its analogs in enzyme-linked immunosorbent assay (ELISA) (mean \pm S.E., $n=3$ ).

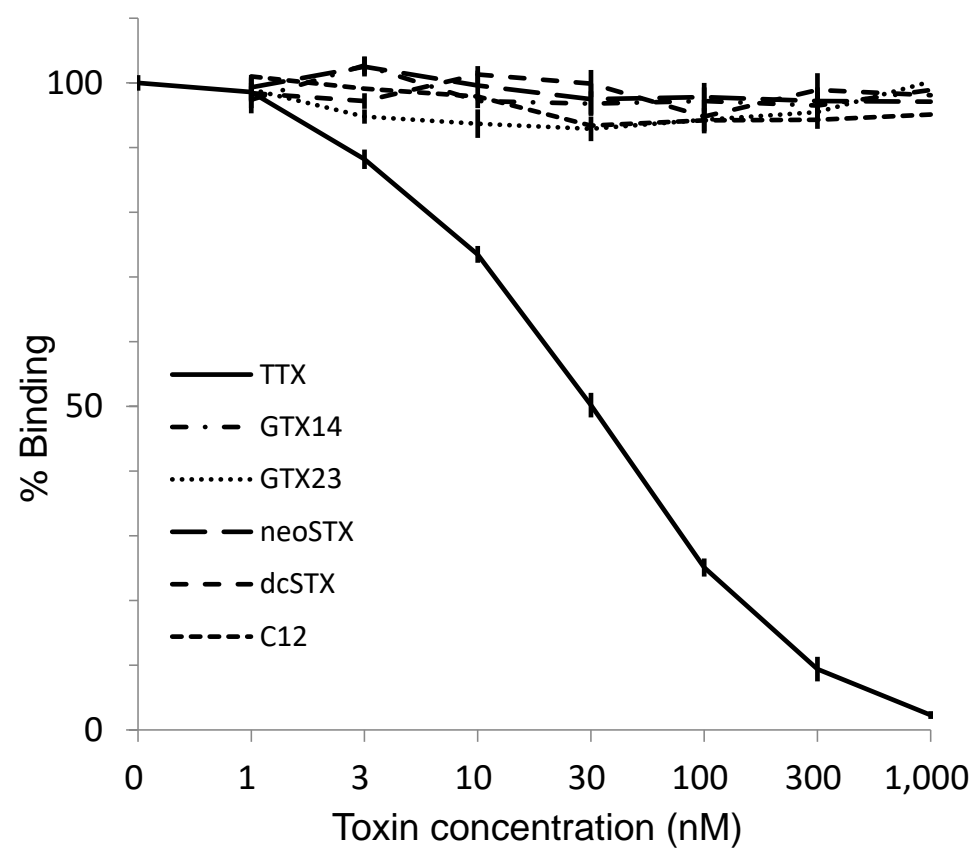

Figure 6. The reactivity of the antibody against paralytic shellfish toxins in ELISA (mean \pm S.E., $n=3$ ). 


\section{Discussion}

A newly designed antigen (KLH-TTX) was inoculated into five rabbits for seven months to obtain a specific polyclonal antibody, which reacted well with TTX and its analogs except for 4,9-anhydroTTX. Because 4-epiTTX, 11-oxoTTX and 5,6,11-trideoxyTTX showed high cross-reactivity, C9 position of TTXs seems to be an important part for the recognition by the antibody.

Not only TTX but also various TTX analogs have been found in toxic organisms such as pufferfish [18,19]. Among these analogs, 5,6,11-trideoxyTTX could be a de novo product of TTXs (Figure 7), although biological conversions from deoxy derivatives to TTX have not been clearly demonstrated along with the origin(s) of TTX. Yasumoto et al. [11] reported that some marine bacteria produce TTX and 4,9-anhydroTTX, but the amount produced by these bacteria cannot well explain a high level of TTX accumulated in toxic organisms. TTX itself is water-soluble and likely to be hardly accumulated in organisms through the food web. It has been reported that the monoclonal antibody developed for TTX by Kawatsu et al. has quite low cross-reactivity for 4,9-anhydroTTX [25]. As shown in Figures 3 and 5, the antibodies obtained from rabbits No. 2 and No. 3 also hardly recognized 4,9-anhydroTTX. Actually, the antiserum from rabbit No. 3 showed the lowest titer as shown in Figure 2. However, subsequent experiments for purification of the antiserum were performed with this rabbit antiserum, because we aimed to save the antisera of other rabbits for future investigations such as cellular localization of TTX and its analogs and examination of their metabolic pathways.

Development of new antibody for this toxin is expected to be produced in the future. Cross-reactivities of the other TTX derivatives such as 5,6,11-trideoxyTTX and 11-oxoTTX by the monoclonal antibodies already developed for TTX have not been reported. This is the first report of a new antibody which has wide range affinities on various TTX analogs.

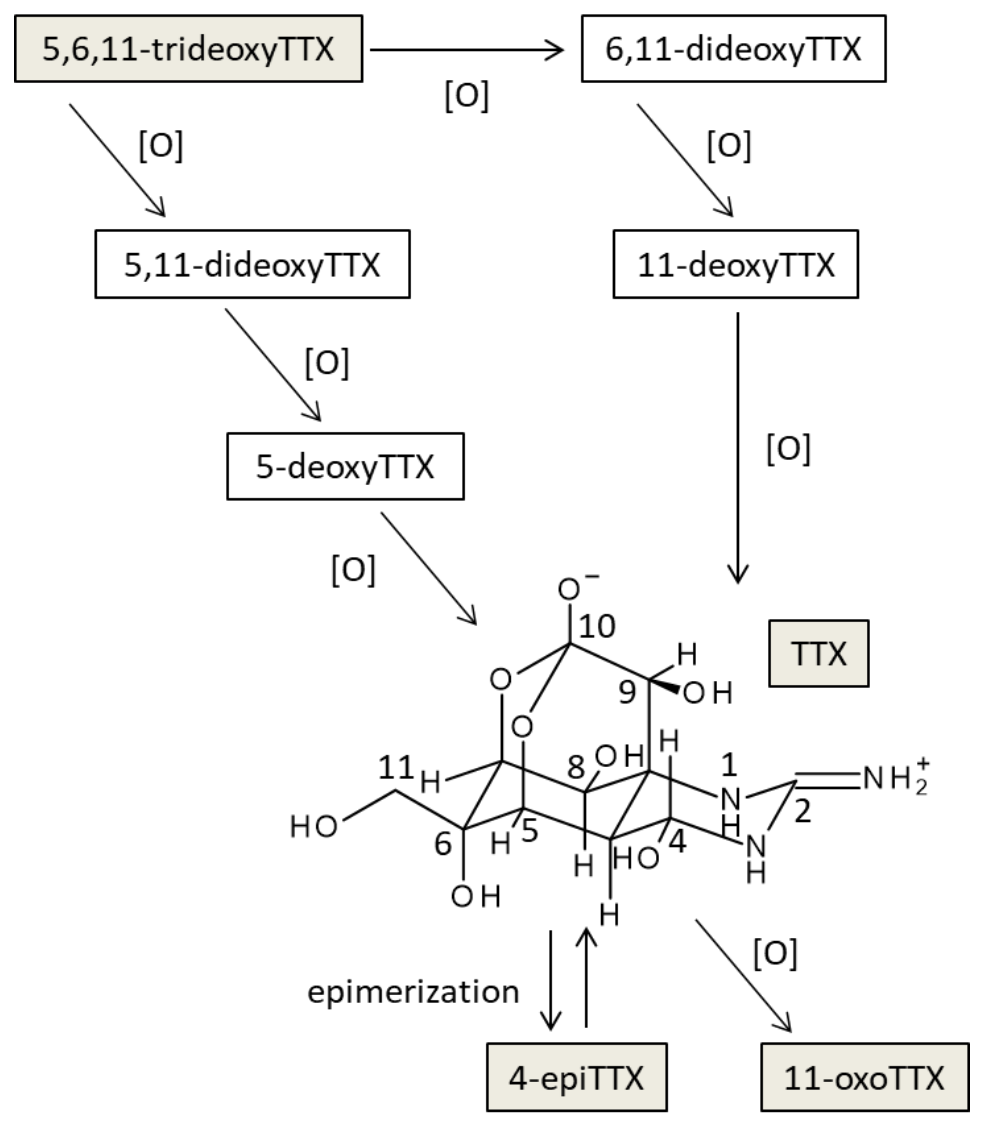

Figure 7. The estimated conversion pathways of TTX and its analogs in toxic organisms (partially modified from Yotsu-Yamashita et al. [19]). 
The ELISA system using this specific antibody was also developed in the present study. So far, pufferfish toxin, mainly TTX, has been quantified by mouse bioassay [37]. However, mouse bioassay has negative aspects because it requires the use of laboratory animals and its sensitivity is not efficient. Recently, methods of liquid chromatography with MS detector as well as post-column derivatization fluorometric monitor have been developed to detect TTX and its analogs [21,38]. Currently, however, only a limited number of authorized references of TTX analogs are available for quantification of these LC analyses. Immuno-chemical methods have high sensitivity and specificity, and usually, a number of samples can be treated at a time. We are sure that our newly developed polyclonal antibody with analytical procedures using direct one-step ELISA is useful, not only to detect TTX and its analogs in various aquatic organisms, but also to disclose the mechanisms involved in metabolic pathways and accumulation of TTXs in toxic organisms.

No cross-reaction was observed when PST components such as GTX1/4, GTX2/3, C1/2, neoSTX nor dcSTX were analyzed by the ELISA. TTXs and PSPs are voltage-dependent sodium channel blockers. The guanidino groups of TTXs and PSPs are essential to this pharmacological activity. The antibody in the present study is obtained from a novel antigen in which C4 position of TTX is coupled to a carrier protein while the guanidino group of TTX remains. The structure of antigen (Figure 1) can explain that the specific structures of TTX and its analogs except 4,9-anhydroTTX were well recognized by the polyclonal antibody, but not for PSTs.

ELISA technique for summed PSTs concentration has been reported [36,39]. In comparison to them, sensitivity for TTX on ELISA in the present study seems to be insufficient. Some improvements may be achieved when the antisera of rabbits No. 2 and 5 is used after purification.

\section{Conclusions}

A polyclonal antibody against TTX based on a new haptenic antigen was developed. This antibody reacts well with not only TTX but also 4-epiTTX, 11-oxoTTX, 5,6,11-trideoxTTX but not with 4,9-anhydroTTX, indicating the deference on C9 position of TTX analogs affects significantly on the cross-reaction. A direct one-step ELISA system using this novel antibody well recognizes various TTX analogs in high sensitivities. The polyclonal antibody newly designed ELISA system can be expected as useful tools for studies on distributions of TTX and its analogs, as well as biosynthetic mechanisms of TTX in toxic aquatic organisms.

\section{Material and Methods}

\subsection{Materials}

Toxic pufferfish Takifugu pardalis, T. snyderi, T. flavipterius (former T. poecilonotus), and T. porphyreus were collected from a fish market in Ofunato, Iwate Prefecture, Japan, from April to July in 2016. Frozen samples of Takifugu rubripes and Lagocephalus sceleratus were supplied from the Enoshima Aquarium, Fujisawa, Kanagawa Prefecture, Japan, in December 2016.

\subsection{Preparation of TTX and Its Analogs}

TTX and its analogs were extracted from the visceral part of fish with $0.1 \%$ acetic acid by heating in a boiling water bath for $10 \mathrm{~min}$, according to the method for TTX described in Standard Methods of Analysis in Food Safety, Japan [37]. TTX and its analogs, 4,9-anhydroTTX and 5,6,11-trideoxyTTX, were isolated by successive column chromatography on activated charcoal (for chromatography; Wako, Osaka, Japan), Bio-Gel P-2 (200-400 mesh; Bio-Rad, Hercules, CA, USA), and Bio-Rex 70 (200-400 mesh; Bio-Rad, Hercules, CA, USA) according to the method described by Nagashima et al., [14]. 4,9-anhydroTTX thus isolated was used to prepare the antigen. In addition, an aliquot of isolated TTX (ca. $10 \mu \mathrm{mol}$ ) was dissolved in $5 \mathrm{~mL}$ of $0.1 \%$ acetic acid and heated in boiling water for $30 \mathrm{~min}$. 4-epiTTX and 4,9-anhydroTTX produced in the reaction mixture were isolated by Bio-Rex 70 column chromatography (200-400 mesh, $1.5 \times 115 \mathrm{~cm})$ and used as the materials for the examination of their 
cross-reactions with the polyclonal antibody against TTX, which was produced in the present study as described below. Moreover, 11-oxoTTX was prepared from the isolated TTX by treating with the $\mathrm{FeSO}_{4}$ and $\mathrm{H}_{2} \mathrm{O}_{2}$ mixture, according to Wu et al. [40] (Figure S1).

\subsection{Preparation of the EDT and TTX Adduct}

Referring to the reaction between 4,9-anhydroTTX and L-cysteine [18], the adduct of TTX and EDT was prepared as follows. Thirty $\mu \mathrm{mol}$ of 4,9 -anhydroTTX isolated from the pufferfish was dissolved in $20 \mathrm{~mL}$ of $0.05 \mathrm{M}$ ammonium phosphate buffer ( $\mathrm{pH} 8.0$ ) and mixed with $10 \mathrm{~mL}$ of dimethylsulfoxide (DMSO) containing $260 \mu \mathrm{L}$ of EDT. The mixture was incubated at $37^{\circ} \mathrm{C}$ for $30 \mathrm{~min}$, and the produced EDT-TTX adduct was extracted four times with an equal volume of ethyl acetate to remove remaining EDT and DMSO. The extract was loaded on a column of Bio-Gel P-2 (200-400 mesh, $1.5 \times 10 \mathrm{~cm}$ ) to purify the EDT-TTX adduct. The fractions containing the EDT-TTX adduct eluted in diluted acetic acid were combined, lyophilized and dissolved in $1 \mathrm{~mL}$ of $0.1 \mathrm{M}$ sodium phosphate buffer (pH 7.2). Meanwhile, 20 mg keyhole limpet hemocyanin-HG (KLH; CAS. No. 9013-72-3; Wako, Japan) dissolved in $2 \mathrm{~mL}$ of $0.1 \mathrm{M}$ sodium phosphate buffer ( $\mathrm{pH} 7.4$ ) was mixed with $10 \mathrm{mg}$ N-(4-maleimidobutyryloxy) succinimide (GMBS, CAS. No. 80307-12-6; Dojindo, Masuki, Japan) dissolved in $0.3 \mathrm{~mL}$ of $\mathrm{N}$-dimethylformamide. The mixture was allowed to stand at room temperature for $30 \mathrm{~min}$, applied to a column of Sephadex G-25 (fine, $1.5 \times 35 \mathrm{~cm}$; GE Healthcare, Chicago, IL, USA), and eluted with $0.1 \mathrm{M}$ sodium phosphate buffer ( $\mathrm{pH}$ 6.0). While monitoring the eluate by absorption at $280 \mathrm{~nm}$, fractions containing the KLH-GMBS conjugate were collected and adjusted $\mathrm{pH}$ to 7.2 by the addition of $0.1 \mathrm{M}$ sodium hydroxide. The KLH-GMBS conjugate thus obtained was mixed with the EDT-TTX adduct prepared as described above. The mixture was allowed to stand at $5{ }^{\circ} \mathrm{C}$ overnight, dialyzed twice against $1 \mathrm{~L}$ of $0.1 \%$ acetic acid, and then twice against $1 \mathrm{~L}$ of phosphate-buffered saline without $\mathrm{Ca}^{++}$and $\mathrm{Mg}^{++}[\mathrm{PBS}(-)]$, resulting in the production of the TTX-KLH conjugate.

\subsection{Analytical Procedures}

\subsubsection{Confirmation of TTX, 4-epiTTX, and 4,9-anhydroTTX by HPLC-FLD}

TTX, 4-epiTTX and 4,9-anhydroTTX were quantified by fluorometric HPLC using post-column derivatization developed by Yotsu et al. [38] with minor modifications. The details of the HPLC fluorometric analysis are as follows: HPLC column, J-Pak Symphonia C18 (5 $\mu \mathrm{m}, 4.6 \times 150 \mathrm{~mm}$; Jasco, Tokyo, Japan); mobile phase, $0.06 \mathrm{M}$ heptafluorobutiric acid (HFBA, $98 \%$; Sigma-Aldrich, St. Louis, MO, USA) $/ 0.05 \mathrm{M}$ ammonium acetate buffer ( $\mathrm{pH} 5.0$ ), $0.4 \mathrm{~mL} / \mathrm{min}$; reaction reagent, $4 \mathrm{M}$ sodium hydroxide, $0.4 \mathrm{~mL} / \mathrm{min}$; detector, FP-2020 Plus (Jasco, Ex $365 \mathrm{~nm}, \mathrm{Em} 510 \mathrm{~nm}$, Gain $\times 1000$ ); pump for mobile phase, PU-2080 Plus (Jasco, Tokyo, Japan); pump for reaction reagent, PU-2080 Plus (Jasco, Tokyo, Japan); reaction coil, i.d. $0.5 \mathrm{~mm} \times 200 \mathrm{~cm}$ (stainless, $120^{\circ} \mathrm{C}$ in dry oven); integrator, Chromatocorder 21 (SIC, Tokyo, Japan); injection volume, $10 \mu \mathrm{L}$ (overload injection).

\subsubsection{EDT-TTX Adduct and TTX Coupled to KLH}

The amounts of EDT-TTX and TTX coupled to KLH were estimated by the same system as shown in Section 5.4.1. without an HPLC column. Fluorometric peak intensity was compared with that of TTX standard solution $(10 \mu \mathrm{M})$, and its concentration was expressed as TTX equivalent $(\mu \mathrm{M})$.

\subsubsection{Confirmation of 5, 6,11-trideoxyTTX and Labeled Toxin by LC-qTOFMS}

5,6,11-trideoxyTTX and labeled toxin were detected by a LC-QTOFMS (Triple TOF ${ }^{\mathrm{TM}} 5600^{+}$; SCIEX, Framingham, MA, USA) as follows: Column, Atlantis HILIC (Waters, Milford, MA, USA), $3 \mu \mathrm{m}$, $2.1 \times 150 \mathrm{~mm}$; mobile phase A, acetonitrile; mobile phase $\mathrm{B}, 10 \mathrm{mM}$ ammonium formate buffer ( $\mathrm{pH} 4.0$ ); flow rate, $0.2 \mathrm{~mL} / \mathrm{min}$; injection volume, $5 \mu \mathrm{L}$; $\mathrm{CE}$ values, $30 \pm 10 \mathrm{eV}$; gradient, $0 \mathrm{~min}$ (B: 20\%) -15 min (B: $60 \%$ ) -16 $\min$ (B: 60\%)-16.1 $\min$ (B: 20\%)-19 $\min$ (B: 20\%); mode, TOF-MS, operated in a positive ion mode via electrospray ionization. 


\subsubsection{Inoculation of the Haptenic Antigen to Rabbits}

The conjugate of KLH-TTX was immunized to five rabbits. We ordered the inoculation to rabbits and preparation of their sera to Protein Purify Co. (Isezaki, Gunma, Japan). In the first month, $1 \mathrm{~mL}$ of the antigen solution $[0.3 \mathrm{mg} / \mathrm{mL}$ PBS(-)] was inoculated to one rabbit with complete adjuvant biweekly. After one month, rabbits were continuously immunized each with $1 \mathrm{~mL}$ solution of the antigen mixed with an incomplete adjuvant. The rabbits were inoculated 14 times in total for seven months with the antigen, and their sera were collected by exsanguination.

\subsubsection{Monitoring the Antibody Activity}

Five $\mathrm{mL}$ of blood was collected from each rabbit just before immunization, and antibody activity against TTX was monitored after inoculation of the antigen. A $100 \mu \mathrm{L}$ portion of rabbit sera were mixed each with $100 \mu \mathrm{L}$ of TTX solutions corresponding to $2,5,10,20$, or $25 \mu \mathrm{M}$ diluted with PBS(-), and allowed to stand for $30 \mathrm{~min}$ at room temperature. The mixtures were filtered through Nanosep $10 \mathrm{~K}$ Omega (Pall Corporation, Ann Arbor, MI, USA), and TTX in the filtrate was quantified by an HPLC fluorometric analyzer. The titer (antibody activity) was evaluated by the amount of TTX (nmol) trapped by the $1 \mathrm{~mL}$ antiserum. The mixture, in which the antiserum was replaced with PBS(-), was analyzed in the same way and used as a control. In addition, $100 \mu \mathrm{L}$ portion each of 5,6,11-trideoxyTTX, 4-epiTTX, 4,9-anhydroTTX, and 11-oxoTTX were mixed with the sera collected from the rabbits at 7th inoculation, and treated with the same manner as described above to estimate the cross-reactivity.

\subsection{Preparation of Biotin-TTX as a Competitive Labeled Toxin for ELISA}

Biotin-labeled TTX (Biotin-TTX), a competitive labeled toxin for ELISA, was prepared as follows. Freeze-dried 4,9-anhydroTTX ( $5 \mu \mathrm{mol})$, derived from isolated TTX and purified on a Bio-Rex 70 column, was added with $310 \mathrm{mg}$ ( $2 \mathrm{mmol}$ ) of ( \pm )-dithiothreitol (DTT) in $3 \mathrm{~mL}$ of $0.05 \mathrm{M}$ potassium phosphate buffer ( $\mathrm{pH} \mathrm{8.0)}$ and the mixture incubated at $37^{\circ} \mathrm{C}$ for $30 \mathrm{~min}$. The adduct of TTX and DTT produced in the reaction mixture was isolated by column chromatography of Bio-Gel P-2. An aliquot of freeze-dried DTT-TTX ( $3.4 \mathrm{~mol}$ ) was dissolved in $2 \mathrm{~mL}$ of $0.1 \mathrm{M}$ sodium phosphate buffer (pH 7.4) and mixed with $4 \mathrm{mg}$ of EZ-Link Maleimide-PEG2-Biotin (Thermo Fisher Scientific, Waltham, MA, USA). The mixture was allowed to stand for two hours at room temperature, loaded on a column of Bio-Gel P-2, eluted with water, and then with $0.2 \mathrm{M}$ acetic acid. Biotin-TTX in the fractions eluted with $0.2 \mathrm{M}$ acetic acid was monitored by the same method described in Section 5.4.2. The fractions which showed fluorescence peaks beyond $20 \mu \mathrm{M}$ TTX equivalent were combined. The biotin-TTX in the combined solution was confirmed by high-resolution mass (Triple $\mathrm{TOF}^{\mathrm{TM}} 5600^{+}$; SCIEX, Framingham, MA, USA) as follows: Mobile phase, water; flow rate, $0.2 \mathrm{~mL} / \mathrm{min}$; injection volume, $5 \mu \mathrm{L} ; \mathrm{CE}$ values, $30 \pm 10 \mathrm{eV}$; mode, TOF-MS, operated in a positive ion mode via electrospray ionization scanned from $\mathrm{m} / \mathrm{z} 100$ to 1000. The concentration of Biotin-TTX was determined with fluorometric analyzer as described above (Section 5.4.2). The test solutions were filtered through Nanosep 10K Omega prior to these analyses.

\subsection{Preparation of Polyclonal Antibody}

\subsubsection{Preparation of TTX-coupled Affinity Resin}

EAH-Sepharose 4B (GE Healthcare) was washed with water at room temperature, and $10 \mathrm{~mL}$ portion of the resin was mixed with $10 \mathrm{~mL}$ PBS(-) and $56 \mathrm{mg}$ GMBS dissolved in $2.5 \mathrm{~mL}$ DMSO. After $20 \mathrm{~min}$, the slurry was poured into a glass column $(2 \times 3 \mathrm{~cm})$ and washed with $200 \mathrm{~mL}$ water and with $50 \mathrm{~mL}$ PBS(-), successively. Freeze-dried $14 \mu \mathrm{mol}$ DTT-TTX was dissolved in $30 \mathrm{~mL}$ PBS(-) and mixed with the GMBS-treated EAH-Sepeharose 4B. The mixed slurry was gently stirred at room temperature for one hour, and the column was washed with $100 \mathrm{~mL}$ water. To quench the remaining maleimide moiety on the resin, the column was washed with the mixture of $1 \mathrm{~mL} 2$-mercaptoethanol and $100 \mathrm{~mL}$ PBS(-). The column was once again washed with $100 \mathrm{~mL}$ water containing $0.1 \mathrm{~g}$ sodium azide. 


\subsubsection{Purification of Polyclonal Antibody}

An aliquot of TTX-coupled affinity resin obtained as above was packed in a glass column $(1 \times 3 \mathrm{~cm})$ and washed with $100 \mathrm{~mL}$ PBS(-). The precipitate obtained by $50 \%$ saturated ammonium sulfate fractionation from $7.5 \mathrm{~mL}$ portion of antiserum (Rabbit No.3, exsanguinated 2 weeks after the final inoculation) was dissolved in $7.5 \mathrm{~mL}$ PBS(-), loaded on the affinity column, and treated with $60 \mathrm{~mL}$ PBS(-) and $100 \mathrm{~mL}$ of $0.1 \mathrm{M}$ glycine- $\mathrm{HCl}$ buffer ( $\mathrm{pH}$ 2.7), successively, at room temperature. Each $2 \mathrm{~mL}$ fraction eluted with $0.1 \mathrm{M}$ glycine- $\mathrm{HCl}$ buffer was collected in test tubes added beforehand with $400 \mathrm{~L}$ of 1 M 2-amino-2-hydroxymethyl-1,3-propanediol (Tris), while monitoring the absorption at $280 \mathrm{~nm}$ using a spectrophotometer (V-550, Jasco). Isolated antibody specific for TTX and its analogs thus obtained was mixed with an equivalent volume of PBS(-) containing 6 L ProClin 300 (Sigma-Aldrich, 48912-U), divided to each $1 \mathrm{~mL}$, and stored in a deep freezer $\left(-80^{\circ} \mathrm{C}\right)$ until use.

\subsubsection{Direct One Step ELISA for TTX and Its Analogs}

The isolated polyclonal antibody was diluted 100 times with $0.9 \%(w / v) \mathrm{NaCl}$ in $0.01 \mathrm{M}$ Tris- $\mathrm{HCl}$ buffer ( $\mathrm{pH}$ 8.2), and $100 \mu \mathrm{L}$ portions were added to each well of a 96-well ELISA plate (Maxisorp, Thermo Fisher Scientific). After stirring at $5{ }^{\circ} \mathrm{C}$ overnight, the plate was washed with PBS(-) and added each $350 \mathrm{~L}$ Block Ace ( $4 \%$ w/v in water; KAC Co., Ltd., Kyoto, Japan) solution and left at $5{ }^{\circ} \mathrm{C}$ overnight. The plate was washed with PBS(-) containing $0.05 \%(v / v)$ Tween 20 (PBST) twice. The assay procedure is summarized as follows: $50 \mathrm{~L}$ solution of isolated TTX or its analogs (11-oxoTTX, 4-epiTTX, 4,9-anhydroTTX, 5,6,11-trideoxyTTX) at 1-1000 nM in $0.1 \mathrm{M}$ sodium phosphate buffer, $\mathrm{pH} 7.4$, was added to each well of the ELISA plate coated with the antibody. Then, $50 \mathrm{~L}$ Biotin-TTX ( $2 \mathrm{nM}$, diluted with the same buffer) was added to each well and the plate was incubated at $37^{\circ} \mathrm{C}$ for $15 \mathrm{~min}$. While the solution was discarded, the wells were washed with PBST and added with $50 \mathrm{~L}$ HRP-Streptavidin solution [2000 times dilution with PBS(-); Funakoshi, Tokyo, Japan). The plate was incubated at $37^{\circ} \mathrm{C}$ for $15 \mathrm{~min}$ and the solution was discarded. After washing the wells three times with PBST, $100 \mu \mathrm{L}$ Sigma-Fast tablets (OPD- $\mathrm{H}_{2} \mathrm{O}_{2}$, Sigma-Aldrich, dissolved in $10 \mathrm{~mL}$ water) solution were added to each well, the plate was incubated at $37^{\circ} \mathrm{C}$ for $5 \mathrm{~min}$, and the wells were added with $100 \mu \mathrm{L} \mathrm{HCl}(2 \mathrm{M})$. Finally, each well was subjected to measurement of absorbance at $490 \mathrm{~nm}$ with a plate reader (iMark, Bio-Rad). The toxin solution samples were analyzed in triplicate.

\subsection{Cross-Reactivity with Paralytic Shellfish Toxins}

Paralytic shellfish toxins (PSTs) such as gonyautoxin 1/4 (GTX1+4, equilibrated mixture), GTX 2/3, $\mathrm{C} 1 / 2$, neosaxitoxin (neoSTX) and decarbamoylsaxitoxin (dcSTX) were isolated from contaminated bivalves according to the method described in Section 5.2. The concentrations of these toxins in the solution were confirmed by HPLC fluorometric analyzer developed by Oshima [41] in which toxin references were kindly supplied from Dr. Oshima. The isolated toxins were examined for their cross-reactivity on ELISA with the TTX antibody. Briefly, these toxins were dissolved separately in $0.1 \mathrm{M}$ sodium phosphate buffer ( $\mathrm{pH} 7.2$ ) at 1-1000 $\mathrm{nM}$ and examined for their cross-reactivity in the same manner as described above.

\subsection{Ethics Statement}

All animal experiments presented in this study were approved by Animal Experiments Ethical Review Board in Protein Purify Co: Jikken-Dobutsu-Rinri-Iinkai (K17A0710). Approval date: 10 July 2017.

Supplementary Materials: The following are available online at http://www.mdpi.com/2072-6651/11/10/551/s1, Figure S1: Fluorometric HPLC analysis of isolated TTX analogs. In Figure 5, these isolated toxins were analyzed on ELISA. Table S1: Reaction of TTX and its analogues with DDT expressed as concentration of the remaining free toxins measured by HPLC-FLD in function of time. Table S2: The reactivity of the antibody against KLH in ELISA.

Author Contributions: S.S. was responsible for the collection of the samples, the HPLC fluorometric analysis, and supervision of all experimental work and preparation of the manuscript. S.T. assisted to collect the samples, 
and performed all experimental work. K.Y. was mainly responsible for the LC-QTOFMS analysis. S.W. supervised and supported to prepare the manuscript.

Funding: This research was funded by Health Labour Sciences Research Grants grant number H27-ShokuhinIppan-009 from the Japan Ministry of Health, Labour and Welfare.

Acknowledgments: We thank to stuff of the Ofunato Fish Market, Ofunato, Iwate Prefecture, Japan, and the Enoshima Aquarium, Fujisawa, Kanagawa Prefecture, Japan, for supplying pufferfish samples.

Conflicts of Interest: The authors declare no conflict of interest.

\section{References}

1. Narahashi, T.; Moore, J.W.; Posto, R.N. Tetrodotoxin derivatives: Chemical structure and blockage of nerve membrane conductance. Science 1967, 156, 976-979. [CrossRef]

2. Kao, C.Y. Actions of nortetrodotoxin on frog muscle and squid axon. Toxicon 1982, 20, 1043-1050. [CrossRef]

3. Takahashi, D.; Inoko, Y. Unter suchungen über das Fugugift. Cen-tralbl. Meb. Wiss. 1889, 27, 529-530.

4. Takahashi, D.; Inoko, Y. Chemische unter suchungen über das Fugugift. Cen-Tralbl. Meb. Wiss. 1889, 27, 881-882.

5. Tsuda, K.; Ikuma, S.; Kawamura, M.; Tachikawa, R.; Sakai, K.; Tamura, C.; Amakasu, O. Tetrodotoxin. VII. On the structures of tetrodotoxin and its derivatives. Chem. Pharm. Bull. Jpn. 1964, 12, 1357-1374. [CrossRef]

6. Woodward, R.B. The structure of tetrodotoxin. Pure Appl. Chem. 1964, 9, 49-74. [CrossRef]

7. Goto, T.; Kishi, Y.; Takahashi, S.; Hirata, Y. Tetrodotoxin. Tetrahedron 1965, 21, 2059-2088. [CrossRef]

8. Mosher, H.S.; Fuhrman, G.J.; Fuhrman, F.A.; Fischer, H.G. Tarichatoxin-tetrodotoxin, a potent neurotoxin. Science 1964, 144, 1100-1110. [CrossRef]

9. Noguchi, T.; Hashimoto, Y. Isolation of tetrodotoxin from a goby Gobius Criniger. Toxicon 1973, 11, $305-307$. [CrossRef]

10. Kim, Y.H.; Brown, G.B.; Mosher, H.S. Tetrodotoxin: Occurrence in atelopid frogs of Costa Rica. Science 1975, 189, 151-152. [CrossRef]

11. Noguchi, T.; Arakawa, O. Tetrodotoxin-Distribution and accumulation in aquatic organisms, and cases of human intoxication. Mar. Drugs 2008, 6, 220-242. [CrossRef]

12. Biessy, L.; Boundy, M.J.; Smith, K.F.; Harwood, D.T.; Hawes, I.; Wood, S.A. Tetrodotoxin in marine bivalves and edible gastropods: A mini-review. Chemosphere 2019. [CrossRef]

13. Yasumoto, T.; Yasumura, D.; Yotsu, M.; Michishita, T.; Endo, A.; Kotaki, Y. Bacterial production of tetrodotoxin and anhydrotetrodotoxin. Agric. Biol. Chem. 1986, 50, 793-795.

14. Noguchi, T.; Hwang, D.F.; Arakawa, O.; Sugita, H.; Deguchi, Y.; Shida, Y.; Hashimoto, K. Vibrio alginolyticus, a tetrodotoxin-producing bacterium, in the intestines of the fish Fugu vermicularis vermicularis. Mar. Biol. 1987, 94, 625-630. [CrossRef]

15. Simidu, U.; Noguchi, T.; Saito, T.; Shida, Y.; Hashimoto, K. Marine bacteria which produce tetrodotoxin. Appl. Environ. Microbiol. 1987, 53, 1714-1715.

16. Nagashima, Y.; Arakawa, O.; Sato, S. Puffer fish toxin. In Natural History of Toxic Fish and Approaching Mystery; Matsuura, K., Nagashima, Y., Eds.; Hokkaido University Press: Sapporo, Japan, 2015; pp. $33-103$. (In Japanese)

17. Chau, R.; Kalaitzi, J.A.; Neilan, B.A. On the origins and biosynthesis of tetrodotoxin. Aqua. Toxicol. 2011, 104, 61-72. [CrossRef]

18. Bane, V.; Lehane, M.; Dikshit, M.; O’Riordan, A.; Furey, A. Tetrodotoxin: Chemistry, toxicity, source, distribution and detection. Toxins 2014, 6, 693-755. [CrossRef]

19. Vlasenko, A.E.; Velansky, P.V.; Chernyshev, A.V.; Kuznetsov, V.G.; Magarlamov, T.Y. Tetrodotoxin and its analogues profile in nemertean species from the Sea of Japan. Toxicon 2018, 156, 48-51. [CrossRef]

20. Yotsu-Yamashita, M.; Goto, A.; Yasumoto, T. Identification of 4-S-cysteinyltetrodotoxin from the liver of puffer fish, Fugu pardalis, and formation of thiol adducts of tetrodotoxin from 4,9-anhydrotetrodotoxin. Chem. Res. Toxicol. 2005, 18, 865-871. [CrossRef]

21. Yotsu-Yamashita, M.; Abe, Y.; Kudo, Y.; Ritson-Williams, R.; Paul, V.J.; Konoki, K.; Cho, Y.; Adachi, M.; Imazu, T.; Nishikawa, T.; et al. First identification of 5,11-dideoxytetrodotoxin in marine animals, and characterization of major fragment ions of tetrodotoxin and its analogs by high resolution ESI-MS/MS. Mar. Drugs 2013, 11, 799-2813. [CrossRef] 
22. Jang, J.H.; Lee, J.S.; Yotsu-Yamashita, M. LC/MS analysis of tetrodotoxin and its deoxy analogues in the marine puffer fish Fugu niphobles from the southern coast of Korea, and the brackishwater puffer fishes Tetraodon nigroviridis and Tetraodon biocellatus from Southeast Asia. Mar. Drugs 2010, 8, 1049-1058. [CrossRef]

23. Puilingi, C.G.; Kudo, Y.; Cho, Y.; Konoki, K.; Yotsu-Yamashita, M. Tetrodotoxin and its analogues in the pufferfish Arothron hispidus and A. nigropunctatus from the Solomon Islands: A comparison of their toxin profiles with the same species from Okinawa, Japan. Toxins 2015, 7, 3436-3454. [CrossRef]

24. Turner, A.; Fenwick, D.; Powell, A.; Dhanji-Rapkova, M.; Ford, C.; Hatfield, R.; Santos, A.; Martinez-Urtaza, J.; Bean, T.; Baker-Austin, C.; et al. New invasive nemertean species (Cephalothrix Simula) in England with high levels of tetrodotoxin and a microbiome linked to toxin metabolism. Mar. Drugs 2018, 16, 452. [CrossRef]

25. Watabe, S.; Sato, Y.; Nakaya, M.; Hashimoto, K.; Enomoto, A.; Kaminogawa, S.; Yamauchi, K. Monoclonal antibody raised against tetrodonic acid, a derivative of tetrodotoxin. Toxicon 1989, 27, 265-268. [CrossRef]

26. Matsumura, K. A monoclonal antibody against tetrodotoxin that reacts to the active group for the toxicity. Eur. J. Pharmacol. 1995, 293, 41-45. [CrossRef]

27. Matsumura, K. In vivo neutralization of tetrodotoxin by a monoclonal antibody. Toxicon 1995, 33, $1239-1241$. [CrossRef]

28. Kawatsu, K.; Hamano, Y.; Yoda, T.; Terano, Y.; Shibata, T. Rapid and highly sensitive enzyme immunoassay for quantitative determination of tetrodotoxin. Jpn. J. Med. Sci. Biol. 1997, 50, 133-150. [CrossRef]

29. Kodama, M.; Noguchi, T.; Maruyama, J.; Ogata, T.; Hashimoto, K. Release of tetrodotoxin and paralytic shellfish poison from puffer liver by RNase. J. Biochem. 1983, 93, 243-247. [CrossRef]

30. Williams, B.L.; Stark, M.R.; Caldwell, R.L. Intra-organismal distribution of tetrodotoxin in two species of blue-ringed octopuses (Hapalochlaena fasciata and H. lunulata). Toxicon 2009, 54, 345-353. [CrossRef]

31. Mebs, D.; Arakawa, O.; Yotsu-Yamashita, M. Tissue distribution of tetrodotoxin in the red-spotted newt Notophthalmus viridescens. Toxicon 2010, 55, 1353-1357. [CrossRef]

32. Turner, A.D.; Powell, A.; Schofield, A.; Lees, D.N.; Baker-Austin, C. Detection of the pufferfish toxin tetrodotoxin in European bivalves, England, 2013 to 2014. Eurosurveillance 2015, 20, 21009. [CrossRef]

33. Vlamis, A.; Katikou, P.; Rodriguez, I.; Rey, V.; Alfonso, A.; Papazachariou, A.; Zacharaki, T.; Botana, A.M.; Botana, L.M. First detection of tetrodotoxin in Greek shellfish by UPLC-MS/MS potentially linked to the presence of the dinoflagellate Prorocentrum minimum. Toxins 2015, 7, 1779-1807.

34. Mahmud, Y.; Okada, K.; Takatani, T.; Kawatsu, K.; Hamano, Y.; Arakawa, O.; Noguchi, T. Intra-tissue distribution of tetrodotoxin in two marine puffers Takifugu vermicularis and Chelonodon patoca. Toxicon 2003, 41, 13-18. [CrossRef]

35. Sato, S.; Sakai, R.; Kodama, M. Identification of thioether intermediates in the reductive transformation of gonyautoxins into saxitoxins by thiols. Bioorg. Med. Chem. Lett. 2000, 10, 1787-1789. [CrossRef]

36. Sato, S.; Takata, Y.; Kondo, S.; Kotoda, A.; Hongo, N.; Kodama, M. Quantitative ELISA kit for paralytic shellfish toxins coupled with sample pretreatment. J. AOAC Int. 2014, 97, 339-344. [CrossRef]

37. Sato, S.; Kodama, M. Puffer fish toxin. In Shokuhin Eisei Kensa Shishin, Rikagaku-hen; Japanese Society of Food Hygiene, Ed.; Japanese Society of Food Hygiene: Tokyo, Japan, 2015; pp. 813-820. (In Japanese)

38. Yotsu, M.; Endo, A.; Yasumoto, T. An improved tetrodotoxin analyzer. Agric. Biol. Chem. 1989, 53, $893-895$.

39. Eangoor, P.; Indapurkar, A.S.; Vakkalanka, M.; Yeh, J.S.; Knaack, J.S. Rapid and Sensitive ELISA Screening Assay for Several Paralytic Shellfish Toxins in Human Urine. J. Anal. Toxicol. 2017, 41, 755-759. [CrossRef]

40. Wu, B.Q.; Yang, L.; Kao, C.Y.; Levinson, S.R.; Yotsu-Yamashita, M.; Yasumoto, T. 11-oxo-tetrodotoxin and a specifically labelled ${ }^{3} \mathrm{H}$-tetrodotoxin. Toxicon 1996, 34, 407-416. [CrossRef]

41. Oshima, Y. Postcolumn derivatization liquid chromatographic method for paralytic shellfish toxins. J. AOAC Int. 1995, 78, 528-532.

(C) 2019 by the authors. Licensee MDPI, Basel, Switzerland. This article is an open access article distributed under the terms and conditions of the Creative Commons Attribution (CC BY) license (http://creativecommons.org/licenses/by/4.0/). 